\title{
Linoleic acid and arachidonic acid metabolism in human peripheral blood leucocytes: comparison with the rat
}

\author{
BY STEPHEN C. CUNNANE, ${ }^{*}$ P. W. NAPOLEON KEELING, ${ }^{2}$ \\ RICHARD P. H. THOMPSON ${ }^{2}$ AND MICHAEL A. CRAWFORD ${ }^{1}$ \\ ${ }^{1}$ Department of Nutritional Biochemistry, Nuffield Laboratories of Comparative Medicine, \\ Institute of Zoology, London NW $14 R Y$
}

AND

${ }^{2}$ Gastrointestinal Laboratory, The Rayne Institute, St Thomas's Hospital, London SE1 7EH

(Received 23 March 1983 - Accepted 12 October 1983)

\begin{abstract}
1. Peripheral blood leucocytes from human male volunteers and from male rats were incubated in vitro in the presence of ${ }^{14} \mathrm{C}$-labelled linoleic acid $\left(\left[{ }^{14} \mathrm{C}\right] \mathrm{LA}\right)$ or ${ }^{3} \mathrm{H}$-labelled arachidonic acid $\left(\left[{ }^{3} \mathrm{H}\right] \mathrm{AA}\right)$. The time-course of $\left[{ }^{14} \mathrm{C}\right] \mathrm{LA}$ and $\left[{ }^{3} \mathrm{H}\right] \mathrm{AA}$ incorporation into human leucocyte total lipids was maximal at $80-90 \%$ of the initial dose within 20-30 min of dosing the cells.

2. Compared with mixed leucocytes, isolated polymorphonuclear leucocytes were only marginally different in the differential incorporation of $\left[{ }^{14} \mathrm{C}\right] \mathrm{LA}$ and $\left[{ }^{3} \mathrm{H}\right] \mathrm{AA}$ into total lipids.

3. In human leucocytes, $\left[{ }^{14} \mathrm{C}\right] \mathrm{LA}$ was incorporated initially into triglycerides but predominantly into phosphatidylcholine thereafter. In the rat, $\left[{ }^{14} \mathrm{C}\right] \mathrm{LA}$ remained as the free acid $(63 \%)$, with lesser amounts entering the phospholipids $(9 \%)$, monoglycerides-diglycerides $(12 \%)$ and triglycerides $(<1 \%)$.

4. Utilization of $\left[{ }^{14} \mathrm{C}\right] \mathrm{LA}$ by the $\Delta 6$-desaturase was only a minor route of its metabolism in both human and rat leucocytes.

5. ${ }^{3} \mathrm{H}$-labelled prostaglandins $\mathrm{E}_{2}$ and $\mathrm{F}_{2 \alpha}$ accounted for up to $30 \%$ of the radioactivity released into the incubation medium from human leucocytes incubated with $\left[{ }^{3} \mathrm{H}\right] \mathrm{AA}$ for $60 \mathrm{~min}$.

6. Stimulation of phagocytosis in the human leucocytes with latex beads or with unopsonized zymosan did not alter the differential incorporation of $\left[{ }^{14} \mathrm{C}\right] \mathrm{LA}$ or $\left[{ }^{3} \mathrm{H}\right] \mathrm{AA}$ into the leucocyte lipid fractions.
\end{abstract}

The essential fatty acids (EFA) have been recognized as being essential to humans for 35 years (Hansen et al. 1947) but the EFA status of humans is still only assessed on the basis of plasma and erythrocyte fatty acid composition. Static measurement of fatty acid composition can identify proportional imbalances of fatty acids, but it would be valuable if a metabolically active cell population were available in which EFA metabolism could be measured by in vitro techniques. Both platelets and peripheral blood leucocytes might be appropriate for this purpose. The platelet has been widely used to determine prostaglandin (PG) synthesis from arachidonic acid (Bills et al. 1977) and the leucocyte has been similarly used to study leukotriene synthesis from arachidonic acid (Borgeat $e t$ al. 1976). In neither case has the metabolism of other EFA been documented in any detail.

In the present study we have assessed the uptake of ${ }^{14} \mathrm{C}$-labelled linoleic acid $\left(\left[{ }^{14} \mathrm{C}\right] \mathrm{LA}\right)$ and ${ }^{3} \mathrm{H}$-labelled arachidonic acid $\left.\left({ }^{3} \mathrm{H}\right] \mathrm{AA}\right)$ into mixed human peripheral blood leucocytes. We present evidence that both fatty acids are readily taken up into the leucocyte lipid pools but, in comparison with the rat, the pattern of incorporation is markedly different. In both man and the rat, $\Delta 6$-desaturation was a minor route of $\left[{ }^{14} \mathrm{C}\right] \mathrm{LA}$ metabolism, but did appear to be lower in man than in the rat. Basal PG synthesis, although readily monitored in the medium surrounding the leucocytes following incubation with $\left[{ }^{3} \mathrm{H}\right] \mathrm{AA}$, was also a minor metabolic pathway of $\left[{ }^{3} \mathrm{H}\right] \mathrm{AA}$.

* Present address: Efamol Research Institute, Kentville, Nova Scotia B4N 4H8, Canada. 


\section{MATERIALS AND METHODS}

\section{Leucocyte preparation}

Isolation of peripheral blood leucocytes from healthy male volunteers (aged $30-45$ years) and from male Wistar rats $(250-300 \mathrm{~g}$ ) was performed as previously described (Keeling $e t$ al. 1981). Heparinized blood $(50 \mathrm{ml})$ was mixed with $10 \mathrm{ml}$ dextran in saline $(9 \mathrm{~g}$ sodium chloride/1, Dextraven 150; Fisons) and the erythrocytes and platelets allowed to sediment for 20-30 min. The leucocyte-rich supernatant fraction was decanted into $15 \mathrm{ml}$ test-tubes and centrifuged at $250 \mathrm{~g}$ for $5 \mathrm{~min}$. The supernatant plasma fraction was discarded and the leucocytes resuspended in $3 \mathrm{ml}$ deionized water for $15 \mathrm{~s}$ to lyse contaminating erythrocytes. Quadruple-strength Hartmann's solution $(1.0 \mathrm{ml})$ was added to restore osmolarity and the leucocytes were then centrifuged for $3 \mathrm{~min}$ at $250 \mathrm{~g}$ and resuspended in the incubation medium.

\section{Leucocyte incubation}

The incubation medium was TC 199 minimal essential medium (Wellcome) with 20 mMHEPES (Sigma) added as a buffer (final pH 7.4). The leucocytes were resuspended in varying amounts of medium $(5-20 \mathrm{ml})$ according to the experiment. Leucocyte counts and viability tests were performed before and after incubations. Viability was found to be $>95 \%$, as found in previous studies under similar conditions (Keeling et al. 1981).

For the $\Delta 6$-desaturase studies in intact leucocytes, $0.5 \mu \mathrm{Ci}\left[1{ }^{14} \mathrm{C}\right] \mathrm{LA}(10 \mathrm{nmol}$; Amersham International) was incubated with the leucocytes for $30 \mathrm{~min}$ at $37^{\circ}$. In the leucocyte and rat liver microsomal fractions, $\Delta 6$-desaturase assays were run using appropriate cofactors and the particle-free supernatant fractions added to a Tris-buffered medium as previously described (Cunnane \& Wahle, 1981).

The time-course and lipid distribution studies were carried out by resuspending the leucocytes in TC 199 medium with $0 \cdot 5 \mu \mathrm{Ci}$ each of $\left[1-{ }^{14} \mathrm{C}\right] \mathrm{LA}$ and $\left[5,6,8,9,11,12,14,15-{ }^{3} \mathrm{H}\right] \mathrm{AA}$ (Amersham International) simultaneously.

Stimulation of the leucocytes was carried out with either latex beads or unopsonized zymosan (Sigma). Latex beads were incubated with the leucocytes in the ratio 20:1, and zymosan in the ratio $2: 1$, or approximately $100-150 \mu \mathrm{g}$ zymosan/ml incubation medium. The incubations with zymosan were done on a time-course basis: $1 \mathrm{~h}$ incubation before stimulation, followed by sampling at $1 \mathrm{~h}$ and $2 \mathrm{~h}$ after stimulation. Comparisons of lipid incorporation and distribution were made between stimulated and unstimulated cells.

\section{Lipid extraction}

To determine the lipid incorporation and distribution of $\left[{ }^{14} \mathrm{C}\right] \mathrm{LA}$ and $\left[{ }^{3} \mathrm{H}\right] \mathrm{AA}$, the leucocyte lipids were extracted with chloroform-methanol $(2: 1, \mathrm{v} / \mathrm{v})$ containing butylated hydroxytoluene $(100 \mathrm{mg} / \mathrm{l})$ as an antioxidant. Lipid extracts were spotted on Whatman LK5D pre-coated plates (Pierce and Warriner) which were developed with the following solvents: for neutral lipids (light petroleum (b.p. 40-60)-diethyl ether-acetic acid-methanol (85:15:2.5:1, by vol.); for phospholipids, chloroform-methanol-water $(60: 30: 4$, by vol.). After development, radioactive peaks on all plates were identified using a radiochromatogram scanner (Panax). Lipid bands on the plates were further identified by charring and comparison with authentic standards.

For the $\Delta 6$-desaturase assay, the incubation was stopped and the lipids saponified with ethanolic potassim hydroxide followed by acidification, extraction with diethyl ether, neutralization, and methylation with diazomethane (Cunnane \& Wahle, 1981). Argentation thin-layer chromatography was used for fatty acid separation, according to the number of double bonds, with the solvent hexane-diethyl ether $(40: 60, \mathrm{v} / \mathrm{v})$. 


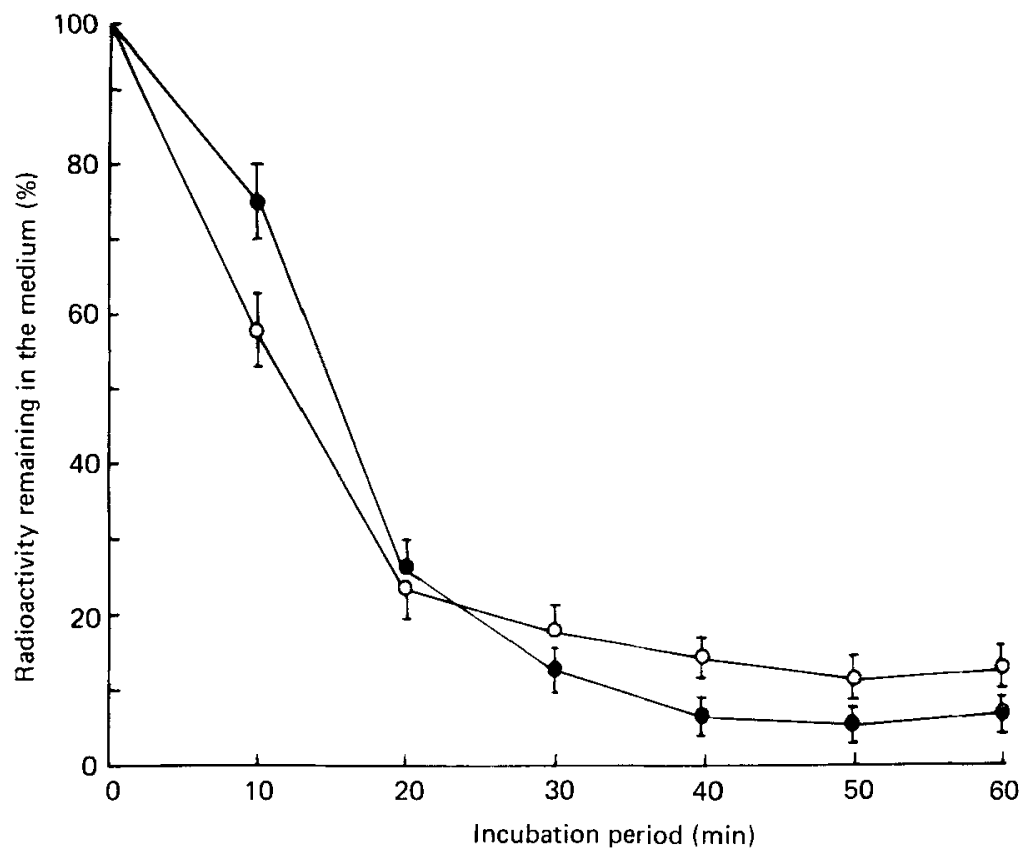

Fig. 1. Time-course of the uptake of $\left[{ }^{14} \mathrm{C}\right]$ linoleic acid $(\mathrm{O})$ and $\left[{ }^{3} \mathrm{H}\right]$ arachidonic acid $(O)$ into human leucocytes. Points are mean values with their standard errors, represented by vertical bars, for four experiments utilizing $1-2 \times 10^{7}$ cells/incubation. [ ${ }^{14} \mathrm{C}$ llinoleic acid was absorbed less rapidly than $\left[{ }^{3} \mathrm{H}\right]$ arachidonic acid at $10 \mathrm{~min}(P<0.01)$ but more rapidly from 40 to $60 \mathrm{~min}(P<0.05)$.

$\mathrm{PGE}_{2}$ and $\mathrm{PGF}_{2 \alpha}$ synthesis from $\left[{ }^{3} \mathrm{H}\right] \mathrm{AA}$ was determined by acidification of the incubation mixture to $\mathrm{pH} 3 \cdot 2$, extraction of the prostaglandins with diethyl ether-ethyl acetate $(4: 1, \mathrm{v} / \mathrm{v})$ and thin-layer chromatographic separation of $\mathrm{PGE}_{2}$ and $\mathrm{PGF}_{2 \alpha}$ using the organic phase of a mixture of ethyl acetate-iso-octane-acetic acid-water $(10: 5: 2: 11$, by vol.) as solvent.

For all radioactivity studies, bands of silica containing radioactivity were scraped into scintillation vials, $10 \mathrm{ml}$ toluene-based scintillation fluid was added and the radioactivity determined using a liquid-scintillation counter (Intertechnique).

Statistical analyses were performed using Student's paired $t$-test.

\section{RESULTS \\ $\left[{ }^{14} \mathrm{C}\right] L A$ and $\left[{ }^{3} \mathrm{H}\right] \mathrm{AA}$ uptake}

Fig. 1 shows the time-course of $\left[{ }^{14} \mathrm{C}\right] \mathrm{LA}$ and $\left[{ }^{3} \mathrm{H}\right] \mathrm{AA}$ uptake from the incubation medium by the leucocytes. For both fatty acids, at least $50 \%$ of the label had been incorporated into the leucocytes within $15 \mathrm{~min}$, and within $30 \mathrm{~min}$ incorporation was maximal. The amount of $\left[{ }^{14} \mathrm{C}\right] \mathrm{LA}$ remaining in the incubation medium was significantly less than that of $\left[{ }^{3} \mathrm{H}\right] \mathrm{AA}$ after $40 \mathrm{~min}$.

\section{Incorporation of $\left[{ }^{14} \mathrm{C}\right] L A$ and $\left[{ }^{3} H\right] A A$ into mixed leucocytes $\mathrm{v}$. separated polymorphonuclear leucoctyes}

The incorporation of $\left[{ }^{14} \mathrm{C}\right] \mathrm{LA}$ and $\left[{ }^{3} \mathrm{H}\right] \mathrm{AA}$ into the lipid fractions of populations of mixed leucocytes (polymorphonuclear and mononuclear leucocytes) and separated polymorphonuclear leucocytes were compared (Table 1). There were only minor differences in the 
Table 1. Comparison of percentage ${ }^{14} \mathrm{C}$-labelled linoleic acid $\left(\left[{ }^{14} \mathrm{C}\right] L A\right)$ and ${ }^{3} \mathrm{H}$-labelled arachidonic acid $\left(\left[{ }^{3} H\right] A A\right)$ incorporation into mixed leucocytes and that of separated polymorphonuclear $(P M N)$ leucocytes utilizing $1-2 \times 10^{7}$ cells/incubation

(Each value is the mean of two determinations)

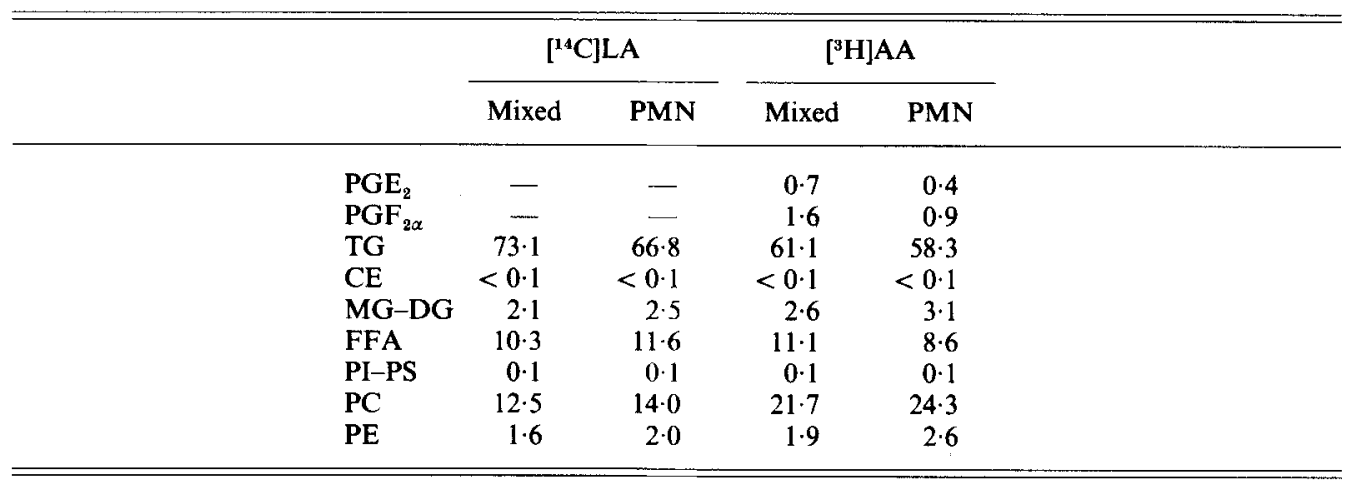

PG, prostaglandin; TG, triglyceride; CE, cholesteryl ester; MG, monoglyceride; DG, diglyceride; FFA, free fatty acid; PI, phosphatidylinositol; PS, phosphatidylserine; PC, phosphatidylcholine; PE, phosphatidylethanolamine.

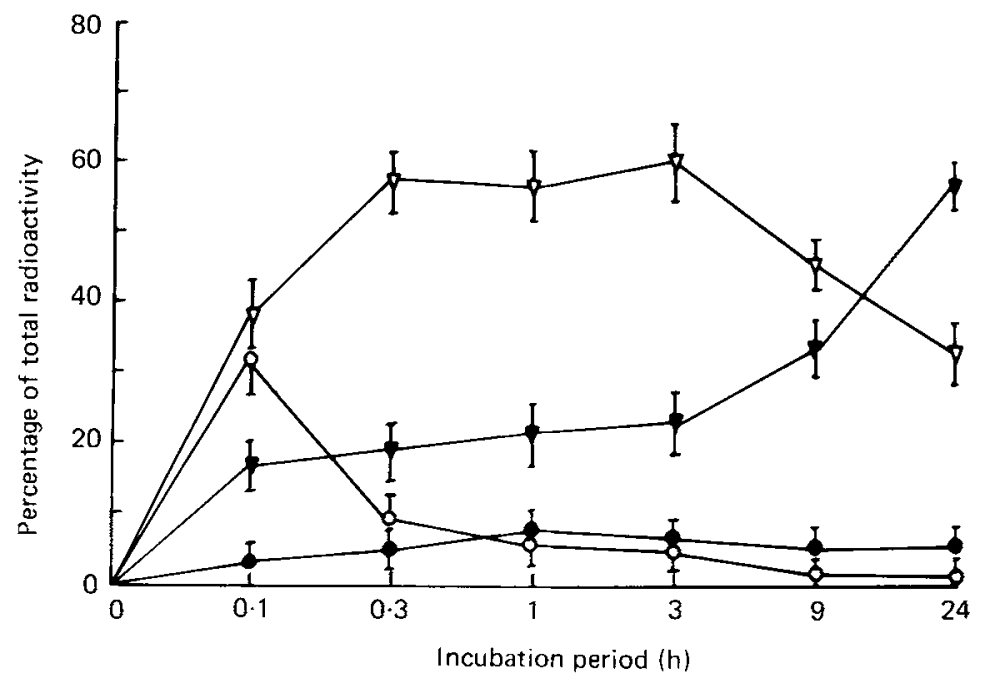

Fig. 2. Time-course of the distribution of $\left[{ }^{14} \mathrm{C} /\right.$ linoleic acid in human leucocyte lipids over $24 \mathrm{~h}$ : triglycerides $(\nabla)$, free fatty acids $(O)$, phosphatidylcholine $(\nabla)$, phosphatidylethanolamine $(O)$. Points are mean values with their standard errors, represented by vertical bars, for four experiments utilizing $1-2 \times 10^{7}$ cells/incubation. There was less [ $\left.{ }^{14} \mathrm{C}\right]$ linoleic acid in phosphatidylcholine than in triglyceride at all time-points except $24 \mathrm{~h}(P<0.01)$, and less $\left[{ }^{14} \mathrm{C}\right]$ linoleic acid in the free fatty acid fraction than in phosphatidylcholine at all time-points except $0.1 \mathrm{~h}(P<0.01)$.

incorporation of both $\left[{ }^{14} \mathrm{C}\right] \mathrm{LA}$ and $\left[{ }^{3} \mathrm{H}\right] \mathrm{AA}$ into triglycerides (TG) and phosphatidylcholine (PC), so all further experiments were conducted using the mixed population of leucocytes to reduce handling of the cells and maintain high viability.

$\left[{ }^{14} C\right] L A$ incorporation into leucocyte lipids

The $24 \mathrm{~h}$ time-course of $\left[{ }^{14} \mathrm{C}\right] \mathrm{LA}$ incorporation into leucocyte lipids is shown in Fig. 2. At $0.1 \mathrm{~h}, 60 \%$ of the $\left[{ }^{14} \mathrm{C}\right] \mathrm{LA}$ was already incorporated into tissue lipids, predominantly TG, which remained the main pool of $\left[{ }^{14} \mathrm{C}\right] \mathrm{LA}$ accumulation for at least $9 \mathrm{~h}$. The amount of 


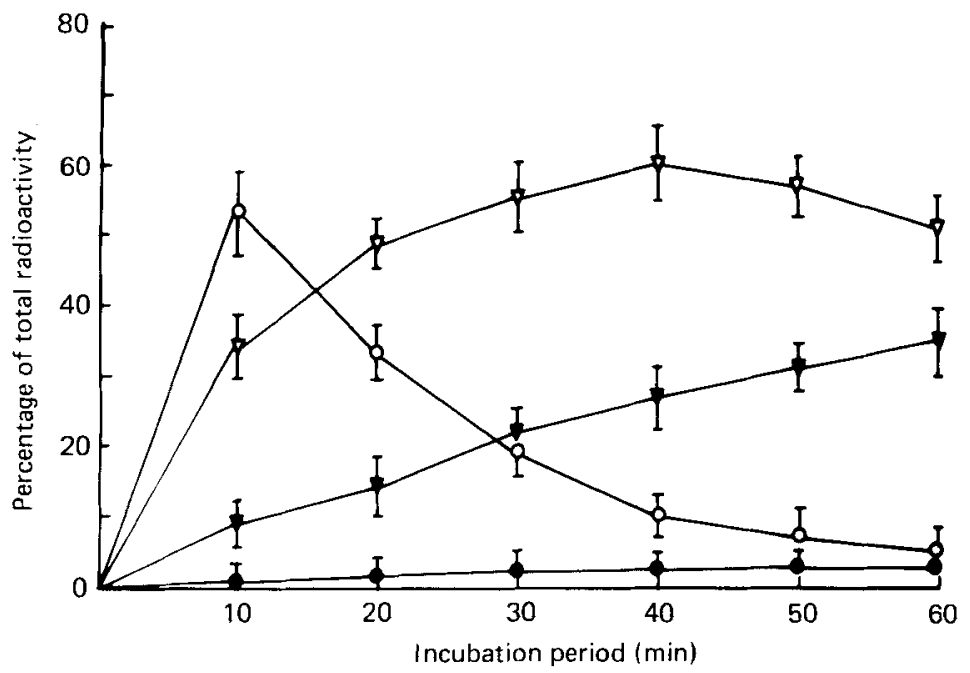

Fig. 3. Time-course of $\left[{ }^{3} \mathrm{H}\right]$ arachidonic acid distribution in human leucocyte lipids over $60 \mathrm{~min}$ : triglyceride $(\nabla)$, free fatty acid $(O)$, phosphatidylcholine $(\nabla)$, phosphatidylethanolamine $(O)$. Points are mean values with their standard errors, represented by vertical bars, for four experiments utilizing $1-2 \times 10^{7}$ cells/incubation. There was less radioactivity incorporated into the phosphatidylcholine fraction than into triglyceride at all time-points to $60 \mathrm{~min}(P<0.01)$ and less radioactivity in the free fatty acid fraction than in triglyceride at all time-points except $10 \mathrm{~min}(P<0.01)$.

$\left[{ }^{14} \mathrm{C}\right] \mathrm{LA}$ in the TG pool peaked at $50-60 \%$ of the total $\left[{ }^{14} \mathrm{C}\right] \mathrm{LA}$ incorporated at between $0 \cdot 3$ and $3 \mathrm{~h}$. This amount was variable between subjects. The amount of $\left[{ }^{14} \mathrm{C}\right] \mathrm{LA}$ incorporated into the $\mathrm{PC}$ fraction increased to a maximum at $24 \mathrm{~h}$. Phosphatidylethanolamine (PE) took up about $5-7 \%$ of the $\left[{ }^{14} \mathrm{C}\right] \mathrm{LA}$ within $0.3 \mathrm{~h}$ and this did not change significantly within $24 \mathrm{~h}$. The amount of $\left[{ }^{14} \mathrm{C}\right]$ LA remaining as the free fatty acid (FFA) in the leucocyte lipids was maximal at about $30 \%$ and occurred at the $0.1 \mathrm{~h}$ time-point, after which it decreased to $5 \%$ at $24 \mathrm{~h}$. The other lipid fractions measured, i.e. monoglycerides (MG), diglycerides (DG), cholesteryl esters (CE), phosphatidylinositol (PI), and phosphatidylserine (PS) accumulated no more than $1 \%$ of the total incorporated $\left[{ }^{14} \mathrm{C}\right] \mathrm{LA}$ at all time-points measured.

\section{$\left[{ }^{3} H\right] A A$ incorporation into leucocyte lipids}

The time-course of $\left[{ }^{3} \mathrm{H}\right] \mathrm{AA}$ incorporation into human leucocyte lipids is shown in Fig. 3. Since the major short-term $(<6 \mathrm{~h})$ changes in the lipid distribution of $\left[{ }^{14} \mathrm{C}\right] \mathrm{LA}$ occurred within $1 \mathrm{~h}$ of dosing the cells, a time-course within this time-period only was studied with $\left[{ }^{3} \mathrm{H}\right] \mathrm{AA}$. Over $1 \mathrm{~h}$, the incorporation of $\left[{ }^{3} \mathrm{H}\right] \mathrm{AA}$ was similar to that of $\left[{ }^{14} \mathrm{C}\right] \mathrm{LA}$, but the lipid distrubution was different: significantly more $\left[{ }^{3} \mathrm{H}\right] \mathrm{AA}$ was incorporated into the $\mathrm{PC}$ fraction and less into the TG fraction. At $20 \mathrm{~min}$, significantly more $\left[{ }^{3} \mathrm{H}\right] \mathrm{AA}$ remained as the FFA than did [ $\left.{ }^{14} \mathrm{C}\right] \mathrm{LA}$. As with $\left[{ }^{14} \mathrm{C}\right] \mathrm{LA},<1 \%$ of the incorporated $\left[{ }^{3} \mathrm{H}\right] \mathrm{AA}$ was found in the MG, DG, CE, PI, or PS fractions up to $1 \mathrm{~h}$ after dosing. In addition, $<0.8 \%$ of the $\left[{ }^{3} \mathrm{H}\right] \mathrm{AA}$ remaining in the leucocytes was converted to $\left[{ }^{3} \mathrm{H}\right] \mathrm{PGE}_{2}$ or $\left[{ }^{3} \mathrm{H}\right] \mathrm{PGF}_{2 \alpha}$.

\section{$\left[{ }^{3} \mathrm{H}\right] \mathrm{AA}$ incorporation into lipids in the incubation medium}

The distribution of $\left[{ }^{3} \mathrm{H}\right] \mathrm{AA}$ in the lipids present in the incubation medium showed a different pattern from that in the leucocyte intracellular lipids (Fig. 4). $\left[{ }^{3} \mathrm{H}\right] \mathrm{PGE}_{2}$ and $\left[{ }^{3} \mathrm{H}\right] \mathrm{PGF}_{2 \alpha}$ were major products of $\left[{ }^{3} \mathrm{H}\right] \mathrm{AA}$ metabolism by the leucocytes and were detected in the incubation medium after $20 \mathrm{~min}$. The amount of conversion of $\left[{ }^{3} \mathrm{H}\right] \mathrm{AA}$ to lipoxygenase products was not measured. The amount of $\left[{ }^{3} \mathrm{H}\right] \mathrm{AA}$ remaining as the FFA decreased rapidly to a 


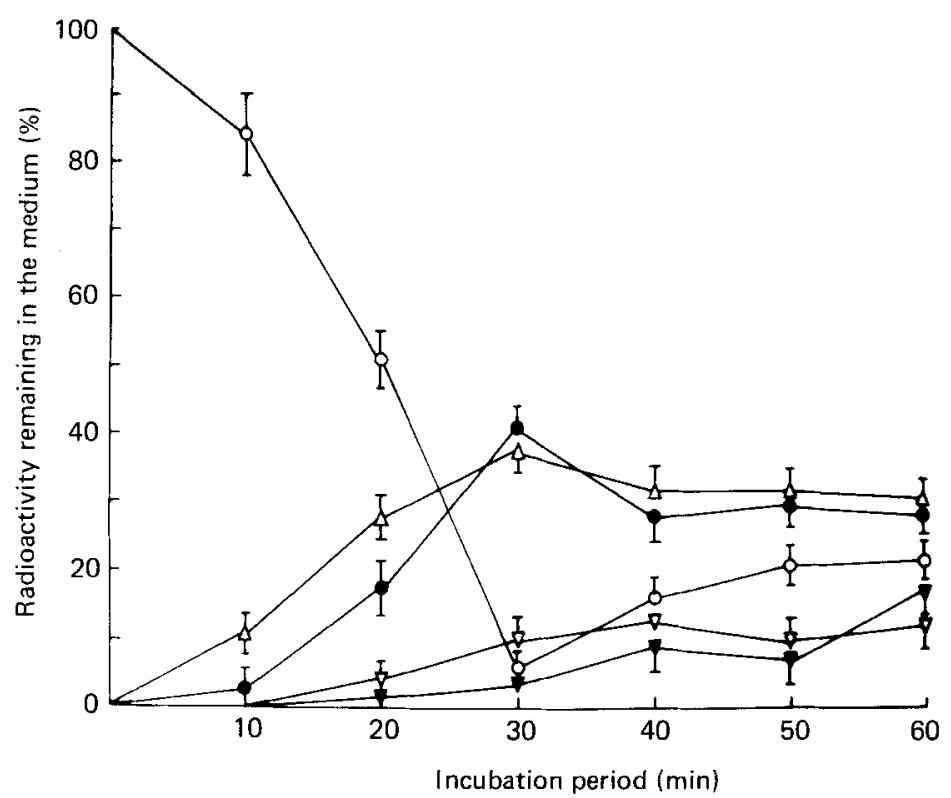

Fig. 4. Time-course of $\left[{ }^{3} \mathrm{H}\right]$ arachidonic acid incorporation into the leucocyte incubation medium over 60 min: $\mathrm{PGE}_{2}(\nabla), \mathrm{PGF}_{2 \alpha}(\nabla)$, free fatty acid $(\bigcirc)$, neutral lipid $(\triangle)$, phospholipid $(\bullet)$. Points are mean values with their standard errors, represented by vertical bars, for four experiments utilizing $1-2 \times 10^{7}$ cells/incubation. There was less $\left[{ }^{3} \mathrm{H}\right]$ arachidonic acid remaining as the free fatty acid after $30 \mathrm{~min}$ than was incorporated into the neutral lipids or phospholipids $(P<0.01)$, and less $\left[{ }^{3} \mathrm{H}\right]$ arachidonic acid converted to $\mathrm{PGF}_{2 \alpha}$ after 20 min than was in the neutral lipid or phospholipid fractions $(P<0.01)$.

minimum at $30 \mathrm{~min}$ which coincided with the rate of its incorporation into the leucocyte lipids. In the incubation medium, the amount of $\left[{ }^{3} \mathrm{H}\right] \mathrm{AA}$ in the neutral lipids and phospholipids was similar: $\left[{ }^{3} \mathrm{H}\right] \mathrm{AA}$ in the phospholipids was equally distributed between PC and PE and in the neutral lipids was mainly in the MG and DG fractions $(60-70 \%)$, with much smaller amounts in the TG fraction than in the intact cells. Very little $(0.5 \%)$ $\left[{ }^{3} \mathrm{H}\right] \mathrm{AA}$ was detected in the PI, PS or CE fractions in the incubation medium.

\section{Leucocyte stimulation}

Stimulation of phagocytosis with latex beads in the presence of $\left[{ }^{14} \mathrm{C}\right] \mathrm{LA}$ and $\left[{ }^{3} \mathrm{H}\right] \mathrm{AA}$ did not significantly affect the intracellular lipid distribution pattern of these fatty acids. Zymosan particles $(100-150 \mu \mathrm{g} / \mathrm{ml})$ also did not significantly affect incorporation of $\left[{ }^{14} \mathrm{C}\right]$ LA or $\left[{ }^{3} \mathrm{H}\right] \mathrm{AA}$ into TG, PC, PE or FFA fractions up to $24 \mathrm{~h}$ after stimulation.

\section{$\left[{ }^{14} \mathrm{C}\right]$ LA desaturation}

The rate of conversion of $10 \mathrm{nmol}(0 \cdot 5 \mu \mathrm{Ci})\left[{ }^{14} \mathrm{C}\right] \mathrm{LA}$ to $\left[{ }^{14} \mathrm{C}\right]-\gamma$-linolenic acid and $\left[{ }^{14} \mathrm{C}\right]$ dihomo$\gamma$-linolenic acid ( $\Delta 6$-desaturase and elongase products respectively) and then to $\left[{ }^{14} \mathrm{C}\right] \mathrm{AA}$ ( $\Delta 5$-desaturase product) during $30 \mathrm{~min}$ incubation is shown in Table 2 . The results are expressed both as a percentage of the total radioactivity recovered as products of $\left[{ }^{14} \mathrm{C}\right] \mathrm{LA}$ and as pmol $\left[{ }^{14} \mathrm{C}\right] \mathrm{LA}$ converted $/ 10^{7}$ cells. The total $\Delta 6$ - and $\Delta 5$-desaturase products of $\left[{ }^{14} \mathrm{C}\right] \mathrm{LA}$ were greater in the leucocyte microsomal fraction than in the intact cells when expressed on the basis of percentage total radioactivity recovered $(1.77 v .2 \cdot 71, P<0.01)$. 
Table 2. Percentage incorporation and distribution of ${ }^{14} \mathrm{C}$-labelled linoleic acid $\left(\left[{ }^{14} \mathrm{C}\right] L A\right)$ into rat and human leucocyte lipids after $1 \mathrm{~h}$ incubation using $2-3 \times 10^{7}$ cells (human) or $4-5 \times 10^{6}$ cells (rat)

(Mean values with their standard errors for five determinations)

\begin{tabular}{|c|c|c|c|c|}
\hline & \multicolumn{2}{|c|}{ Human } & \multicolumn{2}{|c|}{ Rat } \\
\hline & Mean & $\mathbf{S E}$ & Mean & $\mathrm{SE}$ \\
\hline $\begin{array}{l}\text { Percentage }\left[{ }^{14} \mathrm{C}\right] \mathrm{LA} \\
\text { in supernatant } \\
\text { fraction }\end{array}$ & $5 \cdot 2$ & $2 \cdot 0$ & $18 \cdot 2^{* *}$ & $5 \cdot 1$ \\
\hline Free fatty acid & $9 \cdot 4$ & $1 \cdot 4$ & $73.0^{* *}$ & $5 \cdot 1$ \\
\hline $\begin{array}{l}\text { Monoglyceride- } \\
\text { diglyceride }\end{array}$ & 0.3 & 0.1 & $12 \cdot 3^{* *}$ & 5.2 \\
\hline Total phospholipid & $23 \cdot 1$ & 1.8 & $9.9 * *$ & 0.8 \\
\hline Triglyceride & $63 \cdot 6$ & $3 \cdot 3$ & $0.6 * *$ & 0.3 \\
\hline
\end{tabular}

** $P<0.01$.

Table 3. Products of $\Delta 5$ - and $\Delta 6$-desaturation of ${ }^{14} \mathrm{C}$-labelled linoleic acid in human leucocytes, rat leucocytes and rat liver microsomal fractions

(Mean values with their standard errors; results based on a $1 \mathrm{~h}$ incubation of intact leucocytes or a 30 min incubation of the microsomal fractions)

\begin{tabular}{|c|c|c|c|c|c|c|}
\hline & \multicolumn{2}{|c|}{$\begin{array}{c}{\left[{ }^{14} \mathrm{C}\right] \gamma \mathrm{LA} \text { and }} \\
{\left[{ }^{14} \mathrm{C}\right] \mathrm{D} \gamma \mathrm{LA}}\end{array}$} & \multicolumn{2}{|c|}{$\left[{ }^{14} \mathrm{C}\right] \mathrm{AA}$} & \multicolumn{2}{|c|}{ Total products } \\
\hline & Mean & $\mathbf{S E}$ & Mean & $\mathbf{S E}$ & Mean & $\mathbf{S E}$ \\
\hline \multicolumn{7}{|l|}{ Human } \\
\hline \multicolumn{7}{|l|}{ Intact leucocyte $(n 6)$ : } \\
\hline Percentage radioactivity & 0.72 & $0 \cdot 10$ & 1.05 & 0.11 & 1.77 & $0 \cdot 12$ \\
\hline $\mathrm{pmol} / \mathrm{h}$ per $10^{7}$ cells & $9 \cdot 05$ & $1 \cdot 25$ & $13 \cdot 5$ & 1.84 & $22 \cdot 6$ & $1 \cdot 71$ \\
\hline \multicolumn{7}{|l|}{$\begin{array}{l}\text { Leucocyte microsomal fraction } \\
(\text { (n 3): }\end{array}$} \\
\hline Percentage radioactivity & 1.01 & $0 \cdot 16$ & $1 \cdot 70$ & $0 \cdot 15$ & $2 \cdot 71$ & $0 \cdot 24$ \\
\hline $\mathrm{pmol} / \mathrm{h}$ per $10^{7}$ cells & $9 \cdot 16$ & $1 \cdot 31$ & $15 \cdot 7$ & 1.64 & $24 \cdot 9$ & $1 \cdot 57$ \\
\hline \multicolumn{7}{|l|}{ Rat } \\
\hline \multicolumn{7}{|l|}{ Intact leucocyte $(n$ 6): } \\
\hline Percentage radioactivity & $1 \cdot 13^{*}$ & $0 \cdot 23$ & 1.51 & 0.40 & $2 \cdot 64^{* *}$ & $0 \cdot 31$ \\
\hline $\mathrm{pmol} / \mathrm{h}$ per $10^{7}$ cells & $79 \cdot 4^{* *}$ & $4 \cdot 62$ & $107 \cdot 9 * *$ & $8 \cdot 19$ & $186 \cdot 3^{* *}$ & $9 \cdot 28$ \\
\hline $\begin{array}{l}\text { Liver microsomal fraction } \\
(\text { ( 2): }\end{array}$ & & & & & & \\
\hline Percentage radioactivity & 1.62 & $0 \cdot 31$ & $10 \cdot 2 \ddagger$ & 0.87 & $11 \cdot 8_{+}^{+}$ & 0.98 \\
\hline
\end{tabular}

$\left[{ }^{14} \mathrm{C}\right] \gamma \mathrm{LA},\left[{ }^{14} \mathrm{C}\right]-\gamma$-linolenic acid; $\left[{ }^{14} \mathrm{C}\right] \mathrm{D} \gamma \mathrm{LA},\left[{ }^{14} \mathrm{C}\right]$ dihomo- $\gamma$-linolenic acid; $\left[{ }^{14} \mathrm{C}\right] \mathrm{AA},\left[{ }^{14} \mathrm{C}\right]$ arachidonic acid. Mean values were significantly different from those of human leucocytes: ${ }^{*} P<0.05, * * P<0.01$.

Mean values were significantly different from those of intact human or rat leucocytes: $\uparrow P<0.05, \ddagger P<0.01$.

\section{Comparison with rat leucocytes}

Table 2 illustrates the differences in the distribution of $\left[{ }^{14} \mathrm{C}\right] \mathrm{LA}$ into the leucocyte lipids in rats and humans. After $1 \mathrm{~h}$ incubation, $73 \%$ of the $\left[{ }^{14} \mathrm{C}\right]$ LA still remained as the FFA in the rat leucocytes, compared with only $9 \%$ in the human leucocytes. Differences in the incorporation of $\left[{ }^{14} \mathrm{C}\right] \mathrm{LA}$ into phospholipids ( $9 v .26 \%$ in humans) and the MG-DG fraction (12 $v .1 \%$ in humans) also occurred, but the major difference was in the TG fraction: 
$<1 \%$ of the $\left[{ }^{14} \mathrm{C}\right] \mathrm{LA}$ was incorporated into TG in the rat leucocytes whereas in the human leucocytes it was $60 \%$.

Table 3 illustrates the differences of desaturation of $\left[{ }^{14} \mathrm{C}\right] \mathrm{LA}$ by leucocytes from man and the rat. The intact rat leucocytes had an eightfold greater activity of $\Delta 5$ - and $\Delta 6$-desaturases combined than did human leucocytes (measured on the basis of pmol $\left[{ }^{14} \mathrm{C}\right] \mathrm{LA}$ converted $/ 10^{7}$ cells). Both rat and human leucocytes were less capable of desaturating $\left[{ }^{14} \mathrm{C}\right] \mathrm{LA}$ than was rat liver $(P<0.001)$.

\section{DISCUSSION}

Our observtions suggest that the human peripheral blood leucocyte may be a useful cell in which to study EFA metabolism. Both $\left[{ }^{14} \mathrm{C}\right] \mathrm{LA}$ and $\left[{ }^{3} \mathrm{H}\right] \mathrm{AA}$ were rapidly incorporated into TG and PC lipid pools whereas, in the rat, the majority of these labelled fatty acids remained as the free acids. These results give a possible explanation for the apparent difference in desaturation of $\left[{ }^{14} \mathrm{C}\right] \mathrm{LA}$ between humans and the rat, which we have observed. If this difference (Table 3 ) is a real one, it may be linked to a difference in the rate of uptake of $\left[{ }^{14} \mathrm{C}\right] \mathrm{LA}$ into the leucocyte lipids and not just to the rate of conversion of LA to its desaturase products (Table 2). In rat leucocytes, $>60 \%$ of the $\left[{ }^{14} \mathrm{C}\right] \mathrm{LA}$ remained as the FFA for at least $1 \mathrm{~h}$ whereas, in human leucocytes, the intracellular pool of $\left[{ }^{14} \mathrm{C}\right] \mathrm{LA}$ only reached $30 \%$, and after $1 \mathrm{~h}$ was $<10 \%$. Hence the availability of free LA to the desaturase enzyme may be significantly less in the human leucocytes.

Our results also suggest that the TG pool is an important intermediate pool in the incorporation of EFA into human leucocyte cellular lipids. It was the major pool of $\left[{ }^{14} \mathrm{C}\right] \mathrm{LA}$ and $\left[{ }^{3} \mathrm{H}\right] \mathrm{AA}$ accumulation for as long as $9 \mathrm{~h}$ (Fig. 2). In addition, since the FFA pool of $\left[{ }^{14} \mathrm{C}\right] \mathrm{LA}$ and $\left[{ }^{3} \mathrm{H}\right] \mathrm{AA}$ was $<10 \%$ of the total after $30 \mathrm{~min}$, the TG pool may be the short-term precursor pool of these fatty acids for both desaturases and PG synthesis respectively. These results contrast with those in platelets in which AA accumulates almost exclusively in phospholipids (Bills et al. 1977). This metabolic difference with the leucocytes suggests that the functional difference between these cells may be linked to a difference in their EFA metabolism.

Mouse periotoneal macrophages (Bonney et al. 1978, 1981; Scott et al. 1980) also esterify AA into phospholipids much more rapidly than do human peripheral blood leucocytes. However, rabbit peritoneal macrophages are similar to human peripheral blood leucocytes in their metabolism of LA (Elsbach, 1963, 1964; Cook et al. 1983). In fact, the $24 \mathrm{~h}$ time-course of $\left[{ }^{14} \mathrm{C}\right] \mathrm{LA}$ incorporation into rabbit peritoneal macrophages is virtually identical to that in human peripheral blood leucocytes. Since EFA metabolism in human tissues appears to be more like that in the rabbit and guinea-pig than that in the rat or mouse (Stone $e t$ al. 1979) EFA studies of relevance to man might therefore be more suitably conducted using the rabbit or guinea-pig.

We have confirmed previous reports that production of $\mathrm{PGE}_{2}$ and $\mathrm{PGF}_{2 \alpha}$ by human peripheral blood leucocytes is low and is substantially lower than production by tissue macrophages (Morley, 1981). The low production of PG by peripheral blood leucocytes may be related to the high incorporation of AA into the TG rather than the phospholipid pool. This contrasts with tissue macrophages which readily produce $P G$ but also incorporate AA into phospholipids. The rapid and long-term uptake of AA into TG by peripheral blood leucocytes may therefore be a protective mechanism preventing rapid release of AA for conversion to PG or leukotrienes. Our results also confirm that of Elsbach (1972) and suggest that peripheral blood leucocytes do not alter their uptake of EFA in response to phagocytic stimuli such as latex beads or zymosan.

Our time-course studies of $\left[{ }^{3} \mathrm{H}\right] \mathrm{AA}$ metabolism to $\mathrm{PGE}_{2}$ and $\mathrm{PGF}_{2 \alpha}$ (Figs. 3 and 4) did not establish which pool was the source of free $\left[{ }^{3} \mathrm{H}\right] \mathrm{AA}$ for the cyclo-oxygenase enzyme 
under physiological conditions. This was because the amount of $\left[{ }^{3} \mathrm{H}\right] \mathrm{PGE}_{2}$ and $\left[{ }^{3} \mathrm{H}\right] \mathrm{PGF}_{2 \alpha}$ secreted by the leucocytes in $1 \mathrm{~h}$ was only $2 \%$ of the total intracellular radioactivity, although it accounted for $25-30 \%$ of the radioactivity in the incubation medium. A $2 \%$ change in the amount of radioactivity associated with any of the lipid fractions was within the standard error of the results.

We conclude that the peripheral blood leucocyte may be valuable in the study of EFA metabolism in intact human cells. The possibility that the zinc status of the leucocytes may influence the lipid distribution profile of EFA in the leucocytes, as previously demonstrated in the rat (Cunnane \& Huang, 1982), remains to be elucidated. The rapid uptake and distribution of EFA into four main leucocyte lipid fractions and the ease of sampling and assay should facilitate identification of defects in EFA metabolism in human diseases.

S.C.C. is very grateful to the Lalor Foundation, Wilmington, Delaware, USA, for a post-doctoral fellowship and grant while carrying out this research. P.W.N.K. was a Medical Research Council (UK) Training Fellow during the period of this research.

\section{REFERENCES}

Bills, T. K., Smith, J. B. \& Silver, M. J. (1977). Journal of Clinical Investigation 60, 1-6.

Bonney, R. J., Wightman, P. D., Dalgren, M. E., Humes, J. L. \& Davies, P. (1981). Scandinavian Journal of Rheumatology, Supplement, 40, 53-57.

Bonney, R. J., Wightman, P. D., Davies, P., Sadowski, S. J., Kuehl, F. A. Jr \& Humes, J. L. (1978). Biochemical Journal 176, 433-442.

Borgeat, P., Hamberg, M. F. \& Samuelsson, B. (1976). Journal of Biological Chemistry 251, 7816-7820.

Cook, H. W., Clarke, J. T. R. \& Spence, M. W. (1983). Prostaglandins, Leukotrienes and Medicine 10, 39-52.

Cunnane, S. C. \& Huang, Y-S. (1982). Proceedings of the Fifth International Conference on Prostaglandins, Florence, Abstract 702.

Cunnane, S. C. \& Wahle, K. W. J. (1981). Lipids 16, 771-774.

Elsbach, P. (1963). Biochimica Biophysica Acta 70, 157-167.

Elsbach, P. (1964). Biochimica Biophysica Acta 84, 8-17.

Elsbach, P. (1972). Seminars in Haematology 9, 227-239.

Hansen, H. E., Knott, E. M. \& Weise, H. F. (1947). American Journal of Diseases of Childhood 73, 1-18.

Keeling, P. W. N., Jones, R. B., Hilton, P. J. \& Thompson, R. P. H. (1981). Gut 21, 561-564.

Morley, J. (1981). In Lymphokines, vol. 4, A Forum for Immunoregulatory Cell Products, pp. $377-394$ [E. Pike, editor]. New York: Academic Press.

Scott, W. A., Zrike, J. M., Hamill, A. L., Kempe, J. \& Cohn, Z. A. (1980). Journal of Experimental Medicine 152, 324-335.

Stone, K. J., Willis, A. L., Hart, M., Kirtland, S. J., Kernoff, P. B. A. \& McNichol, P. B. (1979). Lipids 14, $174-180$. 